ART IKEL

E-ISSN: $2615-5028$

\title{
INTERNET ADVERTISING AND CONSUMPTIVE LIFESTYLE OF THE STUDENTS
}

\author{
Rully Khairul Anwar \\ (FIKOM University of Padjadjaran; rully.khairul@unpad.ac.id) \\ Elnovani Lusiana \\ (FIKOM University of Padjadjaran; elnovani.lusiana@unpad.ac.idd) \\ M. Taufiq Rahman \\ (FISIP UIN SGD Bandung; fikrakoe@,uinsgd.ac.id)
}

\begin{abstract}
This paper discusses about how mass media as part of society has been widely used in addition being a media of information and entertainment, as well as a media of persuasion. In this case the researcher looked at the exposure of internet advertising that was part of the effort to promote goods and services from producers to the public as consumers. Researchers were intrigued to find out more about whether advertisements on internet mass media that contain more commercial advertisements and become part of economic activities can affect the behavior of students as teenagers that can lead to consumptive nature that is used to be a lifestyle. The student's consumptive lifestyle as a result of being hit by advertisements on the internet mass media is seen from the number of goods ownership such as female students who have a number of beauty equipment with different brands and gadget more than one. And men are more visible on gadgets alone, they are more likely to have more than one gadget, even though one of them can still be used.
\end{abstract}

\section{Keywords: Advertising, Internet, Mass Media, Consumerism}

\begin{abstract}
Abstrak
Tulisan ini membahas tentang bagaimana media massa sebagai bagian dari masyarakat telah banyak digunakan selain sebagai media informasi dan biburan, digunakan juga sebagai media persuasi. Dalam hal ini para peneliti meneliti paparan iklan internet sebagai media persuasi. Yaitu, media yang merupakan bagian dari upay a untuk mempromosikan barang dan jasa dari produsen ke publik sebagai konsumen. Peneliti tertarik untuk mengetabui lebib lanjut tentang apakah iklan di media massa internet yang mengandung lebih banyak iklan komersial dan menjadi bagian dari kegiatan ekonomi dapat mempengarubi perilaku siswa sebagai remaja yang dapat mengarah pada sifat konsumtif. Gaya hidup konsumtif siswa sebagai akibat gempuran iklan di media massa internet terlihat dari banyaknya kepemilikan barang seperti siswa perempuan yang memiliki sejumlah peralatan kecantikan dengan berbagai merek dan gadget yang lebih dari satu.
\end{abstract}

\section{Kata kunci: Periklanan, Internet, Media Massa, Konsumerisme}




\section{A. INTRODUCTION}

The presence of mass media in the modern society is certainly undeniable. Based on the global village concept of Marshal McLuhan (1992), the whole world is now like a very large village. And that happened because of the presence of the mass media so that the distance and time limits became increasingly faded.

Mass media can basically be divided into two categories, namely print media and electronic media. Print media that can meet the criteria as mass media are newspapers and magazines. While electronic media that meets the criteria of mass media are radio, television broadcasts, films, and online media (internet).

When viewed from the forms of mass media, both printed and electronic, all can be said to not be able to free themselves from messages nuanced in consumerism. This is especially true when it comes to advertising concepts. There is hardly a mass media that does not provide advertisements in various forms and concepts, in the mass media space.

One consequence of the presence of mass media is that all forms of information now become massively communicated and relatively short (even real time). A simple message can be sent to other parts of the world in the shortest possible time. Thus, messages containing the ideology of consumerism have become masscommunicated, especially thanks to the presence of mass media (Anwar, R. K., Rusmana, A., \& Rahman, M. T., 2018).

Frank Jefkins (2012) said that the life of the modern world today is very dependent on advertising. Without advertisements the producers and distributors will not be able to sell their goods and the buyer will not have sufficient information about the products or services he needs. The absence of advertising will have an impact on 
the paralysis of the modern economy. Advertising is even carried out by producers of traditional goods.

Basically, advertisements are used as an attempt to continue the consistency of obtaining profits from producers of goods and services. Mass production requires a massive level of consumption. Consequently, advertising, especially through mass media, is used as a propaganda event that takes place continuously.

According to the semiotic perspective, advertising is a form of symbolic communication whose purpose is more to the production and exchange of meaning. So, how advertising constructs the consumption symbol will have a different mode compared to sending messages that are unidirectional.

Advertising creates a symbolic meaning of a product. The symbolization is then negotiated in such a way by the public. The audience then internalizes the symbolic meanings into them when they consume the product. So that advertising and consumption eventually become a series of processes of internalization of symbolization and meaning.

Mass media through various forms of advertising define class and social categorization. This categorization is mainly related to consumption. Advertising directs people what products should be consumed if they want to be identified with a particular social class. By consuming the products suggested by these advertisements, a person's social class is unwittingly directed by mass media messages through advertisements.

Advertising can be done through electronic or printed media, one of which is the internet. The internet is audiovisual, every picture and sound usually contains an invitation and persuasion. Griffiths added that the internet is the most stimulating 
visual media. Internet advertising is a form of advertising that is easily accessible and influential.

Table 1.

The Rate of Indonesia Media Consumptions 2017

\begin{tabular}{|c|c|}
\hline $\begin{array}{c}\text { Rate of Media Consumption } \\
\text { in Indonesia in 2017 }\end{array}$ & $\begin{array}{c}\text { Consumption Rate in } \\
\mathbf{2 0 1 7}(\mathbf{\%})\end{array}$ \\
\hline Television & 96 \\
\hline Outdoor media & 53 \\
\hline Internet & 44 \\
\hline Radio & 37 \\
\hline Newspaper & 7 \\
\hline Tabloid and Magazine & 3 \\
\hline Source: wartakota.tribunnews.com (Nielsen Cross-Platform Survey 2017)
\end{tabular}

Mass media through various forms of advertising define class and social categorization. This categorization is mainly related to consumption. Advertising directs people what products should be consumed if they want to be identified with a particular social class. By consuming the products suggested by these advertisements, a person's social class is unwittingly directed by mass media messages through advertisements.

In the Nielsen survey Consumer Media View (CMV) is a syndicated survey conducted by Nielsen on 17,000 people over the age of 10 years in 11 Indonesian cities. The 11 cities are Jakarta, Bandung, Yogyakarta, Semarang, Surakarta, Surabaya, Denpasar, Medan, Palembang, Makassar and Banjarmasin. 
This shows that the level of media consumption in Indonesia began to be dominated by internet media, where the percentage was around $44 \%$. This shows that conducting promotional activities through internet media is the right way to attract audiences' attention by introducing advertised products.

Borrow two-order language of signification Roland Barthes; the mass media works in two symbolic 'languages' in communicating. Denotative mass media is interpreted as a means of delivering messages and information. The media convey all the information needed and needed by the audience. However, at the level of the meaning of connotation the mass media is understood to be constructing messages and information which are directed towards the logic of consumerism.

The logic of consumerism is constructed by the media in connotative language. News, for example in the connotative meaning, suggests that the public must consume the latest and most up-to-date news. If you don't consume the latest news, then you have lost the opportunity to become the first person to know (or know best) about what is happening in this world. Up date or not someone about an information is determined by the actual date of whether the person is consuming the news presented by the media. Mass media coverage constructs about consumption of information itself.

The internet as an advertising medium has three main advantages. First, the effect on consumer tastes and perception is pervasive. Second, it can reach a large audience at a low cost. Third, sound and moving images create a strong impact.

In reality, each advertisement can be effective only if the explicit goal must encourage planning, creation and implementation. Advertising must work with forms of marketing communication to reach customers, thus, advertising companies are 
always very interested in evaluating the effectiveness of their advertisements in different media, especially internet advertising.

\section{B. THEORETICAL REVIEW}

In advertising on the internet companies are required to pay attention to the informative aspects of the ad. This is because this aspect is one of the important aspects that will determine the effectiveness of an internet advertisement. According to Lee and Jhonson (2004) states an advertisement must have a strong character both from the type of advertisement, advertising model, and advertising slogan so that the advertisement can be useful and attract consumers to buy or use the product or service advertised.

The community finally has the nature of conformity, they adjust to the trend that is in demand by many parties and circles, so they can appear up to date. To be able to have an attractive appearance, the public must spend some of their money to buy all the necessities they consider important. However, it is not uncommon for most people to buy goods not to see what they really need, but only as part of a desire that is not too necessary.

Among those who have consumptive behavior and who often follow the trend and are often influenced by exposure to advertisements on internet media in this modern era is someone who enters adolescence into adulthood. This period provides stimulus for transitional teenagers to find their identity, they tend to be more concerned with appearance and often ask for input from their friends to look attractive and trendy, because basically they look more at fashion rather than need. It does not matter that the product consumed is cheap so that it can cause various kinds of 


\section{ART IKEL}

problems that have not been guaranteed quality, or expensive products that make quite a lot of money to not be efficient and tend to hedonism.

The existence of modernization makes the level of diversity of human needs increasing. This is an opportunity for producers to compete to provide new innovations. Attractive products with good quality are targeted by every consumer so that more products or services are offered by producers to consumers.

Economic sociology is currently analyzing consumers by paying attention to consumer sentiment, exchange norms from consumers, and transaction networks. However, it also does not focus on consumers as contributors to increased knowledge in the market. The neo-classical consumer choice literature switches to analyzing consumer knowledge. Consumer choices are reconstructed as a stage of the information search process. Consumers try to maximize their enjoyment by making the best choice decisions and minimizing the costs of making these decisions required information processes. In the last decade, neo-classical economics has shifted to the discussion of consumer learning. They develop informational flow models to analyze the role of knowledge in the market.

Consumption in a sociological perspective is clearly not just a fulfillment of physical needs, the more important is the fulfillment of social needs in the form of high social status by having certain goods or consuming other luxury services. Excessive consumption behavior in developing countries can be observed from consumptive behavior among urban teenagers, especially those from the upper classes. Urban teenagers are very easily affected by the flow of fashion and the impulses that come from advertising in various mass media. Starting from the fashion style of clothing and accessories, hairstyles, personal equipment, such as cellphones 
and other gadgets are goods and services that are familiar to urban teenagers because they are heavily imaged through advertising. These teenagers tend to hunt for these goods and services with the most up-to-date models and also the most expensive to show their social status.

Desire to buy something arises because like seeing advertisements on the internet with the seduction of advertisements provided, follow-up friends who follow the mode that is developing, and often attach importance to the prestige so as not to be out of date. This is in line with Sumartono's (2002) opinion that someone will carry out consumptive behavior by referring to what is determined by the reference group. This is explained by Sehiffman and Kanuk (2004), "Reference groups are places for individuals to make comparisons, give values, information, and provide guidance or instructions for consumption".

While advertising messages are a form of delivering information about products and services to the public, because advertising is the main component used in the marketing techniques of producers in the marketing publication of their products. Advertising is designed to attract public attention with the aim that the brand does something that is offered through various media. Formulating messages requires solving four problems, namely: message content, message structure, message format, and message source.

Furthermore, you must first know who will be the main purpose of the slogan are the following criteria.

1) It is new, unusual and unique.

2) Can also use the sound game in words or rhymes.

3) Authenticity of slogan or creativity. Creativity is a process or ability that 
reflects fluency, originality in thinking, and the ability to elaborate (develop, enrich, detail), an idea. A person is expected to have the creativity to write slogans because interesting slogans can be interesting and can be easily remembered by people who see or know.

\section{METHOD}

Based on its purpose, this study is included in the descriptive research categor $y$, namely research that attempts to describe specific details of situations, settings or s ocial relations that take place within the scope of the research subject. Therefore, this type of research is descriptive analytical. This type of research according to J. Vreden bregt is a type of research that attempts to describe complex social realities through si mplification and clarification by utilizing concepts that can explain a social phenomen on analytically.

In an effort to obtain data and information both primary and secondary data $t$ hat are accurately related to the indicators examined in the study used data collection $\mathrm{t}$ echniques through observation, interviews, and documentation. Data collection throu gh direct observation or participant observation was carried out in this study both bef ore and when reducing data. Research takes a role in certain situations and participate $\mathrm{s}$ in the events under study.

\section{RESULTS AND DISCUSSION}

Through the internet, advertisements used by producers in an effort to propagate consumers with the products they offer, can arrive quickly and reach the general public, namely to each of their smartphones. So, many of the companies make advertising on the internet as a tool to gain profit in marketing their products. This is in line with communication theory, namely the Hypodermic Needle Theory which 
states that audiences as mass audiences are affected by strong, fast, and directed mass media so that the audience is able to be affected by the mass media's impact quickly like a bullet. The theory which was coined by Wilbur Schram in 1950, has the assumption that mass media directly and quickly can have a very strong effect on the mass audience. According to him, the communicant or the recipient of the message is considered to be passive or ignorant, and the communicator can fire a great bullet at a helpless audience. Whereas from Schram's opinion, Lazarsfeld expressed his opinion that audiences as mass audiences have active characteristics in choosing products according to their interpretation and needs. It seems that the audience also plays an active role in selecting what products are appropriate, comparing with other products, and providing an interpretation of the content of messages and products advertised through the mass media, especially the internet.

Based on the results of interviews with researchers and resource persons, the reason that is often found is because of curiosity about the product advertised. In this category, usually advertisements about food or beauty products are targeted by consumers. Next, because it was suggested by friends. When there is an advertisement on the internet mass media, and the audience has felt interested in buying it, but still in doubt, whether the product is good or not, the testimony from friends is the reference for trying the product directly.

Although the development of technology is increasingly sophisticated, and most of teenagers especially students are more likely to use gadgets to entertain themselves or search for products through online shopping sites. However, advertisements offered on internet media also include various online shopping sites such as Tokopedia, Shopee, Bukalapak, Lazada, etc. which also target more consumers 


\section{ART IKEL}

by advertising these sites in advertisements including on the internet that can easily reach many people and circles. As a result, the consumptive behavior that was received through online shopping media was based on the influence of the advertisements on the internet mass media.

Travel services such as Traveloka, or hotel rental services such as MrAladin.com, all use the internet to function. And most people know about these services through advertisements on the internet mass media, which in the end try and actualize them.

From these things it can be seen that there is really a great influence that can be generated by advertising on the internet mass media in an economic activity, and makes it easier for producers and companies to market their products so that they can be easily accepted by the public.

Exposure to advertisements contained in the internet mass media, a little more can influence attitudes to foster behavior that can lead to consumptive nature. When the behavior becomes a habit, then the habit unconsciously leads to a lifestyle.

The attitude that can be caused by the reaction of the response to advertising on the internet mass media can vary. There is an attitude that is normal or may not be interested in products that are promoted through advertising, so this kind of attitude will not lead to behavior that leads to consumptive nature. And there are also attitudes caused by these advertisements, which are responsive or in other words, the audience feels attracted to the product being advertised, it can be pushed because of the content of the message delivered, the starring advertising model, or the slogans used. So that attitude can encourage someone to behave consumptively. 
Consumers are not spontaneously influenced by advertisements on the internet mass media that presents a variety of products and services, but there are stages that can make the audience as a hypnotized consumer and finally they decide to buy the product they want.

The student consumptive lifestyle that underlies their behavior is because they are suggested by their friends or often referred to as conformity, as well as curiosity that often arises in students. Because in this case, students as a category of adolescents, have a great curiosity and tend to lack a solid filter foundation than adults, so they try products that they consider attractive with the results they expect.

Based on the interviews of researchers with two speakers from each class, it was found that women were more likely to be often suggested by advertisements about food, beauty products such as shampoo and make up, the style of appearance of advertising models that they considered attractive, to luxury products such as cellphones. While men are more likely to be suggested by advertisements about food and gadgets. The consumptive behavior can be seen from the majority of study program students in class X 2017 who look fashionable and trendy, and make up that they use and own, they usually have more than one lipstick from different brands, and the gadgets they have. Whereas men are more visible from gadgets owned by students, they tend to have more than one handphone, even though one of them can still be used. This proves that women tend to be more consumptive than men, because instinctively women are easily tempted by attractive products coupled with gift bonuses offered. 


\section{E. CONCLUSION}

1. Students argue that commercial advertising is more attractive than public service advertisements. This is because commercial advertising promotes a variety of products that can satisfy people's needs in a more casual way, using models, positive advertising messages, easy to understand, interesting, tempting gifts, unique, original, and inviting.

2. All the characteristics of the advertisement can be witnessed directly by students through the internet with audio, visual and portable influences so that they can attract interest from the audience compared to other media such as TV, radio or print media.

3. The student's attitude towards the advertising reaction does not directly lead to consumptive behavior. There are stages where they as the audience try to examine the content of the message and try to find out the product more deeply by asking friends who already have it, or keeping curiosity for longer until finally deciding to be able to buy the product they deem appropriate and want. Consumptive behavior due to exposure to advertisements on the internet mass media can be seen from the trendy female students' performances, the make-up used, and the gadgets they have. As for men, consumer behavior is more visible in electronic devices such as gadgets owned, most of them have more than one gadget. Here consumerism is tangible rather than need, but more as a lifestyle. 


\section{REFERENCES}

Anwar, Rully Khairul, Agus Rusmana, and M. Taufiq Rahman. 2018. "The Politics Of Information On Traditional Medical Practices In Bandung Barat." MIMBAR, Vol. 34 No 1, 2018 pp. 158-165.

Assmus, Daniel Ulf. 2007. "On the Use and Abuse of Nietzsche for Marketing Communication: Examining Consumer Suspicion toward Advertising."

Barthes, Roland. 1988. The semiotic challenge. New York: Hill and Wang.

Calder, Bobby J., Edward C. Malthouse, and Ute Schaedel. 2009. "An experimental study of the relationship between online engagement and advertising effectiveness." Journal of interactive marketing 23.4 (2009): 321-331.

Elvinaro Ardianto, dkk. 2009. Komunikasi Massa Suatu Pengantar. Bandung: Simbiosa Rekatama Media.

Farid Hamid dan Heri Budianto. 2011. Ilmu Komunikasi Sekarang dan Tantangan Masa Depan, Jakarta: Kencana.

Griffiths, Mark D. 2012. "13 Internet gambling, player protection, and social responsibility." Routledge international handbook of Internet gambling (2012): 227.

Haryanto, Sindung. 2011. Sosiologi Ekonomi. Yogjakarta: Ar-Ruzz Media.

http://wartakota.tribunnews.com/2017/07/31/hasil-survei-masyarakat-kian-gemarmengakses http://wartakota.tribunnews.com/2017/07/31/hasil-surveimasyarakat-kian-gemar-mengakses-media-digital-tapi-penetrasi-tv-masihtinggi. [Accessed 08/03/2018]. 
Jefkins, Frank. 2012. Modern marketing communications. Springer Science \& Business Media.

Jhally, Sut. 2014. The codes of advertising: Fetishism and the political economy of meaning in the consumer society. Routledge.

Katz, Elihu, Paul F. Lazarsfeld, and Elmo Roper. 2017. Personal influence: The part played by people in the flow of mass communications. Routledge.

Kohli, Chiranjeev, Lance Leuthesser, and Rajneesh Suri. 2007. "Got slogan? Guidelines for creating effective slogans." Business Horizons 50.5 (2007): 415422.

McLuhan, Marshall, and Bruce R. Powers. 1992. The global village: Transformations in world life and media in the 21st century. Transformations in World Life.

Resnick, Peter. 2008. Internet message format. No. RFC 5322.

Sehiffman, Leon G and Leslie Lazar Kanuk. 2004. Consumer Behavior. New Delhi: Prentice-Hall.

Sumartono. 2002. Terperangkap dalam Iklan: Meneropong Imbas Pesan Iklan Televisi. Bandung: Alfabeta.

Travers, Max. 2001. Qualitative Research Through Case Studies. London: Sage Publications.

Vredenbregt, J. 1983. Metode dan Teknik Penelitian Masyarakat, Jakarta: PT Gramedia.

Yuniarti, Vinna Sri. 2015. Perilaku Konsumen Teori dan Praktek, Bandung: Pustaka Setia.

Zeff, Robbin Lee, and Bradley Aronson. Advertising on the Internet. John Wiley \& Sons, Inc., 1999. 